\title{
Aquatic Plant Genomics: Advances, Applications, and Prospects
}

\author{
Shiqi Hu, ${ }^{1,2}$ Gaojie Li, ${ }^{1,2}$ Jingjing Yang, ${ }^{1,2}$ and Hongwei Hou ${ }^{1,2}$ \\ ${ }^{1}$ The State Key Laboratory of Freshwater Ecology and Biotechnology, The Key Laboratory of Aquatic Biodiversity and Conservation of \\ Chinese Academy of Sciences, Institute of Hydrobiology, Chinese Academy of Sciences, Wuhan, Hubei 430072, China \\ ${ }^{2}$ University of Chinese Academy of Sciences, Beijing 100049, China
}

Correspondence should be addressed to Hongwei Hou; houhw@ihb.ac.cn

Received 15 December 2016; Revised 11 July 2017; Accepted 30 July 2017; Published 16 August 2017

Academic Editor: Graziano Pesole

Copyright (C) 2017 Shiqi Hu et al. This is an open access article distributed under the Creative Commons Attribution License, which permits unrestricted use, distribution, and reproduction in any medium, provided the original work is properly cited.

Genomics is a discipline in genetics that studies the genome composition of organisms and the precise structure of genes and their expression and regulation. Genomics research has resolved many problems where other biological methods have failed. Here, we summarize advances in aquatic plant genomics with a focus on molecular markers, the genes related to photosynthesis and stress tolerance, comparative study of genomes and genome/transcriptome sequencing technology.

\section{Introduction}

Since the idea was founded in 1986, genomics has become one of the most active and influential leading-edge areas of life sciences. Genome annotation and functional genomics have developed rapidly and penetrated into many areas of life science, profoundly affecting the future development and direction of research. Since the complete genome sequence was demonstrated for the model plant Arabidopsis (Arabidopsis thaliana) [1] and subsequently for rice (Oryza sativa) [2], whole-genome sequencing (WGS) of many species of plants has been carried out [3-6]. However, only a few aquatic plants are among them.

Aquatic plants play an important role in water purification and landscaping. They are also a source of bioenergy, biomass, and human/animal food. The study of aquatic plants, especially at molecular levels, has been of increasing interest. In this review, progress in aquatic plant genomics research involving development and application of molecular markers, comparative genomics, functional genomics, and genome sequencing, as well as future prospects, is summarized.

\section{Molecular Marker: Development and Application in Genomics Research}

DNA-based molecular markers are the most powerful diagnostic tools used to detect genetic polymorphisms at the level of DNA. Currently, dozens of different molecular markers have been employed to assess genetic diversity for phylogenetic analysis and to identify germplasm.

2.1. Genetic Diversity Analysis. Aquatic plants are rich and varied worldwide, including 87 families, 168 genera, and 1022 species [7], resulting in complex and genetically diverse ecosystems. Scientists use molecular markers such as SSR (simple sequence repeat), RAPD (random amplified polymorphic DNA), RFLP (restriction fragment length polymorphism), AFLP (amplified fragment length polymorphism), and ISSR (Intersimple sequence repeat) to reveal individual or group differences among aquatic plants. SSR, also known as microsatellite, is most widely used in the study of genetic diversity of aquatic plants due to its high abundance, high variability, and codominance. For example, SSR analysis of an aquatic macrophyte Sparganium emersum revealed significant genotypic diversity between populations in two rivers, the Swalm and Rur. These populations have different modes of reproduction (sexual or asexual) which is affected by current velocity in river systems [8]. In the study of four Ruppia cirrhosa populations, 12 polymorphic markers (including 10 microsatellite loci and two more by cross amplification with those from $R$. maritima) were developed to reveal population diversity and differentiation [9]. In addition, the findings of genetic diversity based on SSR analysis may contribute to establishing conservation programs for some 
endangered species. For instance, 10 microsatellite markers have been used to assess genetic diversity of Euryale ferox (Nymphaeaceae), a "vulnerable" species in Japan [10]. Uesugi et al. developed 10 microsatellite markers for Nymphoides peltata, another threatened clonal aquatic plant, which allowed evaluation of genetic diversity and conservation design in Japan [11] and assessment of genetic diversity within and between populations in China [12].

AFLP markers combine the characteristics of RFLP and RAPD and are another effective tool to investigate genetic diversity. AFLP analysis of 30 populations of Utricularia australis $\mathrm{f}$. tenuicaulis in Japan showed extremely low genetic diversity within populations in contrast to any other clonal plants. However, many of the investigated populations had highly variable and different genotypes. Character compatibility analysis explained the origin of new genotypes: rare-to-sporadic sexual reproduction, instead of somatic mutations, generated new genotypes [13].

ITS (internal transcribed spacer), ISSR, EST- (expressed sequence tag-) SSR, and other molecular markers have been developed for the analysis of aquatic plant genetic diversity. Analysis of the ISSR markers in Ranunculus nipponicus suggested high genetic differentiation among populations and low genetic diversity within them [14]. Due to the availability of large EST data, EST-SSR, which refers to SSR markers derived from ESTs, has been developed and used in different species. EST-SSR has higher versatility among different species and can be used for comparative genomics studies. Yuan et al. developed EST-SSR loci from an EST dataset generated by next generation sequencing in Nymphoides peltata to analyze and evaluate genetic diversity and structure [15].

To enhance the effectiveness of molecular markers, two molecular markers used in combination have achieved good results. The analysis of an invasive and weedy species in China, Alternanthera philoxeroides (Mart.) Grisb, showed that combined RAPD and ISSR could effectively identify the genetic diversity within populations [16]. These two molecular markers were also used to evaluate the genetic variability of different germplasms of an aquatic food plant, Euryale ferox [17].

2.2. Phylogenetic Analysis. High variability of aquatic plants and complexity of traits and morphology cause difficulties for phylogenetic studies. However, the DNA-based molecular marker technique has obvious advantages in overcoming the morphological limitations and determining the evolutionary relationship between different species.

Cabomba Aubl. is a small genus in the family Cabombaceae, containing 5 species whose identification is problematic due to vegetative similarity among the taxa. Thus in 2015, 13 SSR loci were developed to investigate the genetic structure of $C$. aquatica and assess the validity of the five recognized species [18]. Another example is the sacred lotus (Nelumbo nucifera), economically and ornamentally important in China. Previous classification of the Chinese lotus species relied on plant size, petal color, petal patterning, and other morphological traits. In 2011, dendrograms were constructed by AFLP or 20 novel SSR markers to study genetic relationships among 58 accessions of N. nucifera [19].

Three genomes exist in plant cells: nuclear, chloroplast, and mitochondrial. Due to the differences in structure and function, their evolutionary rate is different, providing alternative traits for phylogenetic studies. To reconstruct the phylogeny of the cosmopolitan aquatic plant family Hydrocharitaceae, DNA sequences from 17 genera were sampled, including eight genes: $18 \mathrm{~S}$ from the nucleus; rbcL, matK, trnK5' intron, rpoB, and rpoC1 from chloroplasts; and cob and atp 1 from mitochondria. The phylogeny showed that the Hydrocharitaceae originated in oriental area and dispersal has been the major factor forming the current transoceanic distribution of Hydrocharitaceae [20]. Moreover, ancestral state reconstruction of gender and leaf morphology provided valuable information for understanding adaptive evolution and leaf phenotype in aquatic monocots.

DNA sequence data from nuclear ribosomal and plastid regions has also been used and confirmed to be more efficient to study phylogenetic relatedness and phenotypic plasticity in aquatic plants. In the study of Veronica sect. Beccabunga, a phylogenetic framework for the group was developed based on these two highly variable molecular markers [21].

2.3. Germplasm Identification. The identification of aquatic plant species is difficult because of interspecific hybridization and cryptic species that are reproductively isolated but have no distinguishing morphological criteria. The morphological constraints can be overcome by molecular markers which detect differences between aquatic plant species objectively and accurately at the level of DNA.

The pondweed genus Potamogeton (Potamogetonaceae) has been known for its ability to hybridize extensively and prevalence of cryptic species. Identification of hybrids in linear-leaved Potamogeton species is difficult due to its inadequate and obscure morphological differences. The origin of Potamogeton $\times$ maëmetsiae, as a new hybrid between two linear-leaved species, $P$. friesii and $P$. rutilus, was determined by AFLP analysis, nuclear (ITS, 5S-NTS (nontranscribed spacer)), and chloroplast (rpl32-trnL intergenic spacer) DNA sequence data [22].

Another species of Potamogeton, P. clystocarpus, is considered an endangered aquatic plant in Texas, but its taxonomic status was uncertain due to the lack of fixed morphological differences between it and two sympatric congeners, $P$. pusillus and $P$. foliosus. The genetic uniqueness of $P$. clystocarpus was confirmed using AFLP markers in combination with sequences of the internal transcribed spacer (ITS) region and the chloroplast trnL-F intron and spacer [23].

\section{Comparative Genomics}

Comparative genomics is an approach to compare the known structure of genes and genomes based on genome mapping and sequencing. Through comparing genomic sequences between different species, we can identify the coding and noncoding regulatory sequences and sequences unique to a given species. Via genome-wide sequence 
alignment, the similarities and differences of nucleotide composition, collinearity relationships, and the order of genes between different species can be understood, and it is conducive to predict genetic analysis and uncover biological evolutionary relationships.

In the study of the bladderwort plant Utricularia gibba, the coding sequences were compared to those in the terrestrial species Arabidopsis, grape, tomato, Mimulus, and papaya genomes using two approaches. First, comparison of Pfam domains and examination of significant differences by LRT (likelihood ratio test) showed no significant differences for most domain groups (97\%). For a more in-depth study of specific differences in the genetic repertoire of $U$. gibba, gene families were classified. Among the total 18,991 gene families, 1275 have no U. gibba members, while 1804 showed expansions in U. gibba compared to others, and some gene families are specifically reduced or lost in U. gibba [24]. Furthermore, these gene families were classified and related to main phenotypic features. Together, the analyses suggest numerous key genes and gene families for further functional confirmation and adaptive roles in $U$. gibba's unique lifestyle and highly specialized body plan [25].

The genome of another aquatic plant Spirodela exhibits a reduced gene number, but it still has representatives of 8255 gene families common to Arabidopsis, tomato, banana, and rice. Some genes are lost, and the copy number of gene families varies, likely consistent with its floating characteristics, compact morphogenesis, and suppression of juvenileto-adult transition [26].

Apart from the above cases, expressed sequence tags (ESTs) have been applied to comparative genomics. Over 12,000 ESTs from the diatom Phaeodactylum tricornutum have been generated, and 5108 sequences have been obtained through assembly. The sequences were compared with those of other eukaryotic algae including the red alga Cyanidioschyzon merolae [27], the green alga Chlamydomonas reinhardtii [28], and the centric diatom Thalassiosira pseudonana [29], whose genomes are available. Through the comparison, differences between the two major diatoms were identified and genes were found encoding ACLs (ATP-citrate lyases), CAs (carbonic anhydrases), and FBAs (Fru-1,6-bisphosphate aldolases), related to general cell metabolism [30].

\section{Functional Genomics}

It has been known from comparative genomics that the relationship between genes can be explained by homologous families. In general, the homologs maintain the same or similar functions during evolution. Thus, the availability of comparative genomics strategies and molecular maps for aquatic plants has facilitated studies on functional genomics.

4.1. Photosynthesis-Related Genes. The unique living environment of aquatic plants has led to considerable interest in their photosynthesis, with several studies in recent years being done at the molecular level.

The aquatic monocot Hydrilla verticillata is a C4 NADPmalic enzyme species in which a facultative $\mathrm{C} 4$ cycle coexists with the C3 cycle (Calvin cycle) in the same cell. A functional genomic approach to identify elements necessary for the C4 system in $H$. verticillata used differential display (DDRT PCR). The study identified 13 genes upregulated or uniquely expressed in $\mathrm{C} 4$ leaves by macroarray analysis, northern and semiquantitative RT-PCR analysis [31]. Among these, one gene (hvpepc4) encoded the $\mathrm{C} 4$ photosynthetic PEPC (phosphoenolpyruvate carboxylase) (which was substantially upregulated especially in the light), two encoded distinct isoforms of PPDK (pyruvate orthophosphate dikinase), and genes encoding an aminotransferase, a transporter, and two chaperonins were also upregulated.

The enzyme Rubisco (ribulose-1,5-bisphosphate carboxylase/oxygenase) assimilates carbon dioxide during photosynthesis and is the most abundant chloroplast enzyme in plants. The genes $(r b c S)$ encoding the small subunit (SSU) of Rubisco comprise a small family in the nucleus, of which six $r b c S$ genes from $L$. gibba genomic libraries were isolated in 1990 [32]. Using specific probes from the $3^{\prime}$-UTR of these genes, SSUl was found to be highly expressed in both roots and fronds, whereas SSU5B was expressed at extremely low level in steady-state root mRNA. The localization of these two gene transcripts was the same in fronds by in situ hybridization, indicating that the expression difference of individual $r b c S$ genes in Lemna between organs may be determined by an organ-specific mechanism that involves posttranscriptional events [33].

Rubisco activase (RCA) is a key regulatory element in photosynthesis in aquatic plants. RACE amplification of two full-length cDNAs encoding RCA (SGrca1 and SGrca2) from the aquatic plant Sagittaria graminea revealed novel alternative splicing of RCA [34]. The analysis of RCA gene expression pattern demonstrates that the aerial and submerged environments regulate RCA gene expression at both transcriptional and posttranscriptional levels.

4.2. Stress-Related Genes. Concerns are mounting about abiotic stresses (e.g., heat, environmental pollution, and heavy metals) in the aquatic environment that affect plant growth. Studying stress-related genes in aquatic plants is of great value in fostering new resistant varieties which can be used for environmental remediation and to monitor environmental pollution.

The HSR (heat shock response) is a regulated response involving many elements $[35,36]$. Comparative studies of two Potamogeton species revealed that heat acclimation leads to species-specific differences in heat response. The study also identified HSFA2 (heat shock transcription factor A2) and its putative target gene CP-sHSP (chloroplast-localized small heat shock protein) and found that the more heat tolerant species maintained a higher transcriptional level of duplicated HSFA2 and CP-sHSP genes in order to overcome severe heat stress [37].

Phytoremediation is an inexpensive, effective, and ecofriendly technology that allows environmental cleanup by plants [38]. Many macrophytes are efficient in treatment of wastewater and accumulation of heavy metals such as arsenic (As) and cadmium (Cd) [39-43]. Previous studies have applied physiological, biochemical, toxicological, and 
cytobiological methods to reveal the responses and mechanisms of As detoxification [44-46]. To study functional genes in this process, a PCS (phytochelatin synthase) gene (CdPCS1) was isolated from the aquatic plant Ceratophyllum demersum using a homology-based PCR approach. The role of CdPCS1 in biosynthesis of PC (phytochelatin) was confirmed by its ability to enhance $\mathrm{Cd}$ and As accumulation in transgenic tobacco and Arabidopsis plants [47]. It was also found that the expression of CdPCS1 in rice enhanced accumulation of As in roots, restricting accumulation in aerial parts including grain [48].

Because the ROS (reactive oxygen species) produced by the interaction between copper ions and oxygen are highly destructive, copper also has adverse effects on environment and biological systems [49]. To elucidate the molecular responses stimulated by excess copper exposure in Lemna gibba, genes with altered expression in the presence of copper were identified by ddPCR. Of the six genes identified, northern hybridization analysis demonstrated that four (callose synthase, HSP90, serine decarboxylase, and the biotin carboxylase subunit of acetyl-coenzyme A carboxylase) increased in expression, while the other two genes (the HAP5 subunit of the heme-activated protein (HAP) transcription factor and the chloroplast nucleoid DNA-binding protein CND41) decreased in expression. Interestingly, the altered expression corresponded to the known mechanism of copper toxicity, enabling their use as biomarkers for copper and other environmental pollutants [50].

How to enhance nutrient utilization efficiency of crops has been the subject of intensive research in recent years. To understand the mechanism of high efficiency nutrient acquisition and utilization, the genes involved in low-sulfur tolerance were isolated from a water hyacinth, Eichhornia crassipes, by a gene mining method. Genes were then overexpressed in Arabidopsis wild-type plants to screen for mutants. Overexpression of the jacalin-related lectin gene $(E c J R L-1)$ resulted in Arabidopsis plants with improved sulfur tolerance, and a role in root elongation under sulfurdeficient conditions was confirmed [51].

\section{Large-Scale Genome/Transcriptome Sequencing and Its Utilization}

The functional genes discussed above were obtained by automated sequencing for bioinformatics analysis and preliminary verification of functions. Up to now, the genome size of many aquatic plants has been determined using flow cytometry (FCM) [52]. This genome size information will lay the foundation for future work in genome sequencing and finding a suitable model plant.

During the past two decades, based on the availability of complete sequences of chloroplast genomes, the chloroplast genome and its evolution have been studied by molecular methods. Among aquatic plants, the sequences of chloroplast genome have been accomplished for Nuphar advena [53], Najas flexilis [54], Elodea canadensis [55], Utricularia foliosa [56], Lemna minor [57], and three other species in different genera of the Lemnoideae-Spirodela polyrhiza, Wolffiella lingulata, and Wolffia australiana [58]. The sequencing technique was also upgraded from the first generation sequencer $\mathrm{ABI} 3100$ and $\mathrm{ABI} 3730$ to high-throughput next-generation sequencing (NGS) technologies, like Illumina, Roche/454, and AB SOLiD [59].

In contrast to chloroplast genomes, the number of sequenced mitochondrial genomes in plants is limited due to their unstable and complex structure. The mitochondrial genome of Spirodela polyrhiza has been sequenced from total genomic DNA [60]. In 2013, the complete nucleotide sequence of mitochondrial for Butomus umbellatus was described and compared to the sequenced angiosperm mitochondrial genomes [61].

Little has been reported about whole genome sequencing (WGS) of aquatic plants. Spirodela polyrhiza, which has the smallest monocot genome to date with the size of $158 \mathrm{Mb}$, was the first genome to be fully sequenced [62]. The genome of sacred lotus (Nelumbo nucifera Gaertn.) was sequenced in 2013 [63]. In 2015, the first draft genome of the aquatic model plant Lemna minor, another genus in the Lemnaceae, became available and will be widely utilized for future biotechnological application and stress physiology research [64].

Next-generation sequencing technologies make it possible to sequence the transcriptomes of nonmodel plants to an unprecedented extent. For example, the transcriptome of Utricularia vulgaris was sequenced by 454 pyrosequencing and compared to the transcriptome of $U$. gibba previously published in 2011 [65, 66]. Additionally, the transcriptome of the submerged aquatic plant Ranunculus bungei has been isolated and sequenced to help us understand the molecular adaptive mechanism to aquatic habitats [67]. The study of some aquatic plants with known medicinal properties is limited due to insufficient genomic and physiological information. Currently, comprehensive analysis of the transcriptome of Nasturtium officinale and Oenanthe javanica has been performed to annotate functional genes, promoting the studies of medicinal properties and corresponding pathways $[68,69]$.

In addition to the rise of genome sequencing, there has also been focus on noncoding RNA (ncRNA). These RNAs are involved in physiological activities across all levels in cells. In 2013, the identification of 81 conserved microRNAs (miRNAs) grouped to 41 miRNA families and 52 novel miRNAs (49 families) was reported in sacred lotus by sequencing small RNA libraries. These miRNAs were predicted to regulate 137 genes related to growth and development and other biological processes in sacred lotus [70]. In 2015, computational approaches were used in miRNA identification in sacred lotus and found 106 conserved miRNAs [71]. By combining experimental and bioinformatic analysis, these miRNAs can be used for further research of their roles in $N$. nucifera.

Though many other types of ncRNAs such as transfer RNA (tRNA), ribosomal RNA (rRNA) and small interfering RNAs (siRNAs) have not yet been reported in aquatic plants, and this "RNA world" will become a focus of attention.

\section{Future Prospects}

Compared with terrestrial plants, the number of aquatic plants is relatively few, but they provide people with food, 
TABLE 1: Summary of the genomics studies and technologies correlated to aquatic plant species discussed in the review.

\begin{tabular}{|c|c|c|}
\hline Genomics studies & Species & Applications \\
\hline \multicolumn{3}{|l|}{ Molecular markers } \\
\hline SSR & $\begin{array}{l}\text { Sparganium emersum [8], Ruppia cirrhosa [9], } \\
\text { Euryale ferox [10], Nymphoides peltata }[11,12]\end{array}$ & Genetic diversity analysis \\
\hline \multirow{4}{*}{ AFLP } & Cabomba aquatic [18], Nelumbon ucifera [19] & Phylogenetic analysis \\
\hline & Utricularia australis [13] & Genetic diversity analysis \\
\hline & Nelumbon ucifera [19] & Phylogenetic analysis \\
\hline & $\begin{array}{l}\text { Potamogeton } \times \text { maëmetsiae [22], } \\
\text { Potamogeton clystocarpus [23] }\end{array}$ & Germplasm identification \\
\hline ISSR & $\begin{array}{c}\text { Ranunculus nipponicus [14], } \\
\text { Alternanthera philoxeroides [16], } \\
\text { Euryale ferox [17] }\end{array}$ & Genetic structure \\
\hline EST-SSR & Nymphoides peltata [15] & Genetic diversity and structure \\
\hline RAPD & $\begin{array}{c}\text { Alternanthera philoxeroides [16], } \\
\text { Euryale ferox [17] }\end{array}$ & Genetic diversity \\
\hline \multirow[t]{2}{*}{$\begin{array}{l}\text { Nuclear, chloroplast, } \\
\text { and mitochondrial markers }\end{array}$} & Hydrocharitaceae(family) [20] & Phylogenetic analysis \\
\hline & $\begin{array}{l}\text { Potamogeton } \times \text { maëmetsiae }[22] \text {, } \\
\text { Potamogeton clystocarpus }[23]\end{array}$ & Germplasm identification \\
\hline$\underline{\text { Plastid markers }}$ & Veronica sect. Beccabunga [21] & Phylogenetic and taxonomic analysis \\
\hline \multicolumn{3}{|l|}{ Comparative genomics } \\
\hline $\begin{array}{l}\text { Interspecies comparative } \\
\text { genomics }\end{array}$ & $\begin{array}{c}\text { Utricularia gibba }[24,25] \\
\text { Spirodela [26] } \\
\text { Phaeodactylum tricornutum [30] }\end{array}$ & $\begin{array}{l}\text { Gene family classification and } \\
\text { functional gene prediction } \\
\text { Adaptive molecular evolution analysis }\end{array}$ \\
\hline \multicolumn{3}{|l|}{ Functional genomics } \\
\hline \multirow[t]{4}{*}{ PCR approach } & Hydrilla verticillata $[31]$ & $\begin{array}{l}\text { Identify elements necessary for } \\
\text { C4 system }\end{array}$ \\
\hline & Potamogeton [37] & $\begin{array}{l}\text { Identify } H S F A 2 \text { and its putative target } \\
\text { gene } C P \text {-sHSP }\end{array}$ \\
\hline & Ceratophyllum demersum [85] & $\begin{array}{c}\text { Identify the role of CdPCS1 in } \\
\text { biosynthesis of PC }\end{array}$ \\
\hline & Lemna gibba [50] & $\begin{array}{l}\text { Elucidate the molecular responses } \\
\text { stimulated by excess copper exposure }\end{array}$ \\
\hline Specific probes from $3^{\prime}-\mathrm{UTR}$ & Lemna gibba [33] & $\begin{array}{l}\text { Analyze the expression of the six } \\
r b c S \text { genes in different organs }\end{array}$ \\
\hline RACE & Sagittaria graminea $[34]$ & $\begin{array}{c}\text { Analyze two } R C A \text { genes(SGrca1 and SGrca2) } \\
\text { expression pattern }\end{array}$ \\
\hline Gene mining method & Eichhornia crassipes [51] & $\begin{array}{c}\text { Isolate genes involving low-sulfur } \\
\text { tolerance to understand the mechanism } \\
\text { of high efficiency nutrient acquisition } \\
\text { and utilization }\end{array}$ \\
\hline \multicolumn{3}{|c|}{ Genome/transcriptome sequencing } \\
\hline Chloroplast genome & $\begin{array}{l}\text { Nuphar advena [53], Najas flexilis [54], } \\
\text { Elodea canadensis [55], Lemna minor [57], } \\
\text { Utricularia foliosa [56], Spirodela polyrhiza, } \\
\text { Wolffiella lingulata and Wolffia australiana [58] }\end{array}$ & $\begin{array}{l}\text { Important source of genetic markers } \\
\text { for phylogenetic analysis } \\
\text { Identify functional coding regions and } \\
\text { sequence outside of coding regions } \\
\text { Chloroplast transformation for } \\
\text { genetic engineering } \\
\text { Evolution of chloroplast genomes }\end{array}$ \\
\hline Mitochondrial genome & $\begin{array}{l}\text { Spirodela polyrhiza [60], } \\
\text { Butomus umbellatus [61] }\end{array}$ & $\begin{array}{l}\text { Study the evolution of monocot } \\
\text { mitochondrial genomes }\end{array}$ \\
\hline
\end{tabular}


TABLE 1: Continued.

\begin{tabular}{|c|c|c|}
\hline Genomics studies & Species & Applications \\
\hline \multirow[t]{3}{*}{ Whole genome } & Spirodela polyrhiza [62] & $\begin{array}{l}\text { Stimulate new insights into } \\
\text { environmental adaptation, ecology, } \\
\text { evolution, and plant development } \\
\text { Future bioenergy applications }\end{array}$ \\
\hline & Nelumbo nucifera [63] & $\begin{array}{l}\text { Study the evolutionary history of the } \\
\text { genome and genes involved in relevant } \\
\text { processes governing the unique features }\end{array}$ \\
\hline & Lemna minor [64] & $\begin{array}{l}\text { Understand the biological and molecular } \\
\text { mechanisms in L. minor } \\
\text { Facilitate future genetically improvements } \\
\text { and biomass production applications } \\
\text { of duckweed species }\end{array}$ \\
\hline \multirow[t]{3}{*}{ Transcriptome } & Utricularia vulgaris $[65,66]$ & $\begin{array}{l}\text { Identify gene losses and duplications } \\
\text { during the course of evolution } \\
\text { Study adaptations related to the } \\
\text { environment and carnivorous habit } \\
\text { and evolutionary processes responsible } \\
\text { for considerable genome reduction }\end{array}$ \\
\hline & Ranunculus bungei [67] & $\begin{array}{l}\text { Study the molecular adaptive mechanism } \\
\text { from terrestrial to aquatic habitats }\end{array}$ \\
\hline & $\begin{array}{l}\text { Nasturtium officinale [68], } \\
\text { Oenanthe javanica [69] }\end{array}$ & $\begin{array}{l}\text { Annotate function genes } \\
\text { Promote the studies of medicinal } \\
\text { properties and corresponding pathways }\end{array}$ \\
\hline MicroRNA & Nelumbo nucifera $[70,71]$ & $\begin{array}{l}\text { Identify conserved microRNAs and } \\
\text { their target genes }\end{array}$ \\
\hline
\end{tabular}

vegetables, pharmaceuticals, fiber materials, and livestock feed. Also, they possess great value to ecology and landscape. Owing to these advantages, basic research involving aquatic plants is becoming increasingly emphasized worldwide. Through progress in aquatic plant genomics, advances have been made in terms of molecular marker development and application, isolation, and sequencing of functional genes, as well as in comparative genomics (Table 1). However, the particularities of aquatic plants have resulted in many deficiencies in understanding, thus lagging behind other model plants and crops, so there is still much to be done in aquatic plant genomics research.

With the rise of massive sequencing technologies, sequence read lengths increase and sequencing cost declines. Now, the third-generation sequencing (TGS) or "next-next" generation sequencing technologies such as the SingleMolecule Real-Time (SMRT ${ }^{\mathrm{TM}}$ ) Sequencing, Heliscope ${ }^{\mathrm{TM}}$ Single Molecule Sequencing, and the Ion Personal Genome Machine $^{\mathrm{TM}}$ are available, which generate longer reads in a faster time with higher accuracy [72]. These newly emerging technologies will have potential for extensive application in aquatic plant genomics research.

In the future, a growing number of aquatic plant whole genomes will be sequenced, which will allow emphasis on gene functional studies. Genome editing, using "molecular scissors" or engineered nucleases, is an effective technology to target DNA or edit gene at specific sites in the genome. Currently, four types of engineered nucleases are used for genome editing: zinc finger nucleases
(ZFNs) [73], engineered meganucleases, transcription activator-like effector nucleases (TALENs) [74-76], and CRISPR (clustered regularly interspaced short palindromic repeats)/Cas9 (CRISPR-associated) system [77]. Among these four tools, TALEN and CRISPR/Cas9 are used more widely in organisms, particularly the CRISPR/Cas9 system owing to its easier and faster operation. TALEN technology has been used to engineer plant crops such as rice, barley, and maize [78-80], and since 2013, CRISPR/Cas9 has been broadly applied to plants including Arabidopsis [81, 82], tobacco $[82,83]$, sorghum, rice $[81,84,85]$, wheat [86], and maize [85]. These technologies can soon be applied to aquatic plant research, allowing identification of genes regulating important traits and construction of abundant mutants by genome editing methods.

In conclusion, to achieve comprehensive development of aquatic plant genomics, we still need to do research into these areas: (i) establishment and optimization of genetic transformation systems; (ii) whole genome deep sequencing and comparative genomics; (iii) transformation of the large fragment gene and functional genomics research; (iv) development and application of various molecular markers; and (v) construction of integrated databases, combining information on genome and proteome sequences, mRNA and protein expression profiles, and other useful information. Indeed, while genomics will facilitate the in-depth study of individual genes, proteins, or biological processes in aquatic plants, it cannot be used as a stand-alone tool. Rather, it should be integrated with other disciplines such as 
molecular biology, genetics, bioinformatics, biochemistry, and physiology, which will rapidly promote the study and understanding of aquatic plants.

\section{Conflicts of Interest}

The authors declare that they have no conflicts of interest.

\section{Acknowledgments}

This work was supported by grants to Dr. Hongwei Hou from supporting project for returnees by the Ministry of Personnel of the People's Republic of China for science and technology activities (2015) and project of the Natural Science Foundation of Hubei Province (2015CFB488).

\section{References}

[1] A. G. Initiative, "Analysis of the genome sequence of the flowering plant Arabidopsis thaliana," Nature, vol. 408, no. 6814, pp. 796-815, 2000.

[2] S. A. Goff, D. Ricke, T. H. Lan et al., "A draft sequence of the rice genome (Oryza sativaL. ssp. japonica)," Science, vol. 296, no. 5565, pp. 92-100, 2002.

[3] Tomato Genome Consortium, "The tomato genome sequence provides insights into fleshy fruit evolution," Nature, vol. 485, no. 7400, pp. 635-641, 2012.

[4] K. F. Mayer, J. Rogers, J. Doležel et al., "A chromsome-based draft sequence of the hexaploid bread wheat (triticumaestivum) genome," Science, vol. 345, no. 6194, 2014.

[5] C. Qin, C. Yu, Y. Shen et al., "Whole-genome sequencing of cultivated and wild peppers provides insights into capsicum domestication and specialization," Proceedings of the National Academy of Sciences of the United States of America, vol. 111, no. 14, pp. 5135-5140, 2014.

[6] P. Schnable, D. Ware, R. Fulton et al., "The b73 maize genome: complexity, diversity, and dynamics," Science, vol. 326, no. 5956, pp. 1112-1115, 2009.

[7] X. W. Zou, "Development of aquatic plants at home and abroad (in Chinese)," China Flowers \& Horticulture, vol. 15, pp. 10-12, 2005.

[8] B. J. Pollux, M. D. Jong, A. Steegh, E. Verbruggen, J. M. GroenendaelVan, and N. J. Ouborg, "Reproductive strategy, clonal structure and genetic diversity in populations of the aquatic macrophyte Sparganium emersum in river systems," Molecular Ecology, vol. 16, no. 2, pp. 313-325, 2007.

[9] J. Martinez-Garrido, M. Gonzalez-Wanguemert, and E. A. Serrao, "New highly polymorphic microsatellite markers for the aquatic angiosperm Ruppia cirrhosa reveal population diversity and differentiation," Genome, vol. 57, no. 1, pp. 57-59, 2014.

[10] A. Imanishi, S. Kaneko, Y. Isagi, J. Imanishi, Y. Natuhara, and Y. Morimoto, "Development of microsatellite markers for Euryale ferox (Nymphaeaceae), an endangered aquatic plant species in Japan," American Journal of Botany, vol. 98, no. 8, pp. 233-235, 2011.

[11] R. Uesugi, N. Tani, K. Goka, J. Nishihiro, Y. Tsumura, and I. Washitani, "Isolation and characterization of highly polymorphic microsatellites in the aquatic plant, Nymphoides peltata (Menyanthaceae)," Molecular Ecology Notes, vol. 5, no. 2, pp. 343-345, 2005.
[12] Y. Y. Liao, X. L. Yue, Y. H. Guo, W. R. Gituru, Q. F. Wang, and J. M. Chen, "Genotypic diversity and genetic structure of populations of the distylous aquatic plant Nymphoides peltata (Menyanthaceae) in China," Journal of Systematics and Evolution, vol. 51, no. 5, pp. 536-544, 2013.

[13] Y. Kameyama and M. Ohara, "Predominance of clonal reproduction, but recombinant origins of new genotypes in the free-floating aquatic bladderwort Uricularia australis f. tenuicaulis (Lentibulariaceae)," Journal of Plant Research, vol. 119, no. 4, pp. 357-362, 2006.

[14] K. Koga, Y. Kadono, and H. Setoguchi, "The genetic structure of populations of the vulnerable aquatic macrophyte Ranunculus nipponicus (Ranunculaceae)," Journal of Plant Research, vol. 120, no. 2, pp. 167-174, 2007.

[15] Y. Y. Yuan, Q. F. Wang, and J. M. Chen, "Development of SSR markers in aquatic plant Nymphoides peltata (Menyanthaceae) based on information from transcriptome sequencing (in Chinese)," Plant Sclence Journal, vol. 31, no. 5, pp. 485492, 2013.

[16] B. Wang, W. Li, and J. Wang, "Genetic diversity of Alternanthera philoxeroides in China," Aquatic Botany, vol. 81, no. 3, pp. 277-283, 2005.

[17] H. Kumar, P. Priya, N. Singh et al., "RAPD and ISSR markerbased comparative evaluation of genetic diversity among Indian germplasms of Euryale ferox: an aquatic food plant," Applied Biochemistry and Biotechnology, vol. 180, no. 7, pp. 1345-1360, 2016.

[18] T. D. Barbosa, R. J. Trad, M. M. Bajay, and M. C. Amaral, "Microsatellite markers isolated from Cabomba aquatica s.L. (Cabombaceae) from an enriched genomic library," Applications in Plant Sciences, vol. 3, no. 11, 2015.

[19] J. Hu, L. Pan, H. Liu et al., "Comparative analysis of genetic diversity in sacred lotus (Nelumbo nucifera Gaertn.) using AFLP and SSR markers," Molecular Biology Reports, vol. 39, no. 4, pp. 3637-3647, 2011.

[20] L. Y. Chen, J. M. Chen, R. W. Gituru, and Q. F. Wang, "Generic phylogeny, historical biogeography and character evolution of the cosmopolitan aquatic plant family Hydrocharitaceae," BMC Evolutionary Biology, vol. 12, no. 1, pp. 1$12,2012$.

[21] F. Y. Ellmouni, M. A. Karam, R. M. Ali, and D. C. Albach, "Molecular and morphometric analysis of Veronica L. section Beccabunga (Hill) Dumort," Aquatic Botany, vol. 136, pp. 95-111, 2017.

[22] J. Zalewska-Gałosz and M. Ronikier, "Potamogeton $\times$ maëmetsiae: a new hybrid between linear-leaved pondweeds from central Europe," Preslia -Praha, vol. 83, no. 3, pp. 259-273, 2011.

[23] J. B. Whittall and S. A. Hodges, "Cryptic species in an endangered pondweed community (Potamogeton, potamogetonaceae) revealed by AFLP markers," American Journal of Botany, vol. 91, no. 12, pp. 2022-2029, 2004.

[24] E. Ibarra-Laclette, E. Lyons, G. Hernández-Guzmán et al., "Architecture and evolution of a minute plant genome," Nature, vol. 498, no. 7452, pp. 94-98, 2013.

[25] L. Carretero-Paulet, T. H. Chang, P. Librado et al., "Genomewide analysis of adaptive molecular evolution in the carnivorous plant Utricularia gibba," Genome Biology \& Evolution, vol. 7, no. 2, p. 444, 2015.

[26] W. Wang and J. Messing, "Status of duckweed genomics and transcriptomics," Plant Biology (Stuttgart, Germany), vol. 17, Supplement 1, pp. 10-15, 2015. 
[27] M. Matsuzaki, O. Misumi, T. Shin-I et al., "Genome sequence of the ultrasmall unicellular red alga Cyanidioschyzon merolae 10D," Nature, vol. 428, no. 6983, pp. 653-657, 2004.

[28] S. S. Merchant, S. E. Prochnik, O. Vallon et al., "The Chlamydomonas genome reveals the evolution of key animal and plant functions," Science, vol. 318, no. 5848, pp. 245-250, 2007.

[29] E. V. Armbrust, J. A. Berges, C. Bowler et al., "The genome of the diatom Thalassiosira pseudonana: ecology, evolution, and metabolism," Science, vol. 306, no. 5693, pp. 79-86, 2004.

[30] A. Montsant, K. Jabbari, U. Maheswari, and C. Bowler, "Comparative genomics of the pennate diatom Phaeodactylum tricornutum," Plant Physiology, vol. 137, no. 2, pp. 500-513, 2005.

[31] S. K. Rao, H. Fukayama, J. B. Reiskind, M. Miyao, and G. Bowes, "Identification of $\mathrm{C} 4$ responsive genes in the facultative C4 plant Hydrilla verticillata," Photosynthesis Research, vol. 88, no. 2, pp. 173-183, 2006.

[32] J. Silverthorne, C. F. Wimpee, T. Yamada, S. A. Rolfe, and E. M. Tobin, "Differential expression of individual genes encoding the small subunit of ribulose-1,5-bisphosphate carboxylase in Lemna gibba," Plant Molecular Biology, vol. 15, no. 1, pp. 49-58, 1990.

[33] J. Silverthorne and E. M. Tobin, "Post-transcriptional regulation of organ-specific expression of individual rbcs mRNAs in Lemna gibba," Plant Cell, vol. 2, no. 12, pp. 1181-1190, 1990.

[34] D. Wang, S. Z. Xie, J. Yang, and Q. F. Wang, "Molecular characteristics and expression patterns of Rubisco activase, novel alternative splicing variants in a heterophyllous aquatic plant, Sagittaria graminea," Photosynthetica, vol. 52, no. 1, pp. 83-95, 2014.

[35] S. K. Baniwal, K. Bharti, K. Y. Chan et al., "Heat stress response in plants: a complex game with chaperones and more than twenty heat stress transcription factors," Journal of Biosciences, vol. 29, no. 4, pp. 471-487, 2005.

[36] E. Vierling, "The roles of heat shock proteins in plants," Annual Review of Plant Physiology and Plant Molecular Biology, vol. 42, pp. 579-620, 1991.

[37] M. Amano, S. Iida, and K. Kosuge, "Comparative studies of thermotolerance: different modes of heat acclimation between tolerant and intolerant aquatic plants of the genus Potamogeton," Annals of Botany, vol. 109, no. 2, pp. 443-452, 2012.

[38] D. E. Salt, R. D. Smith, and I. Raskin, "Phytoremediation," Annual Review of Plant Biology, vol. 49, no. 49, pp. 643-668, 1998.

[39] O. Keskinkan, M. Z. L. Goksu, M. Basibuyuk, and C. F. Forster, "Heavy metal adsorption properties of a submerged aquatic plant (Ceratophyllum demersum)," Bioresource Technology, vol. 92, no. 2, pp. 197-200, 2004.

[40] S. Mishra, R. D. Tripathi, S. Srivastava et al., "Thiol metabolism play significant role during cadmium detoxification by Ceratophyllum demersum, L," Bioresource Technology, vol. 100, no. 7, pp. 2155-2161, 2009.

[41] Q. Sun, W. B. Liu, and C. Wang, "Different response of phytochelatins in two aquatic macrophytes exposed to cadmium at environmentally relevant concentrations," African Journal of Biotechnology, vol. 10, no. 33, pp. 6292-6299, 2011.

[42] R. D. Tripathi, R. Singh, P. Tripathi et al., "Arsenic accumulation and tolerance in rootless macrophyte Najas indica are mediated through antioxidants, amino acids and phytochelatins," Aquatic Toxicology, vol. 157, pp. 70-80, 2014.
[43] U. N. Rai, R. D. Tripathi, N. K. Singh et al., "Constructed wetland as an ecotechnological tool for pollution treatment for conservation of Ganga river," Bioresource Technology, vol. 148, no. 11, pp. 535-541, 2013.

[44] S. Mishra, M. Alfeld, R. Sobotka, E. Andresen, G. Falkenberg, and H. Küpper, "Analysis of sublethal arsenic toxicity to Ceratophyllum demersum: subcellular distribution of arsenic and inhibition of chlorophyll biosynthesis," Journal of Experimental Botany, vol. 67, no. 15, pp. 4639-4646, 2016.

[45] S. Mishra, S. Srivastava, R. D. Tripathi, and P. K. Trivedi, "Thiol metabolism and antioxidant systems complement each other during arsenate detoxification in Ceratophyllum demersum L," Aquatic Toxicology, vol. 86, no. 2, p. 205, 2008.

[46] S. Mishra, G. Wellenreuther, J. Mattusch, H. J. Stärk, and H. Küpper, "Speciation and distribution of arsenic in the nonhyperaccumulator macrophyte Ceratophyllum demersum," Plant Physiology, vol. 163, no. 3, pp. 1396-1408, 2013.

[47] D. Shukla, R. Kesari, S. Mishra et al., "Expression of phytochelatin synthase from aquatic macrophyte Ceratophyllum demersum L. enhances cadmium and arsenic accumulation in tobacco," Plant Cell Reports, vol. 31, no. 9, pp. 16871699, 2012.

[48] M. Shri, R. Dave, S. Diwedi et al., "Heterologous expression of Ceratophyllum demersum phytochelatin synthase, CdPCS1, in rice leads to lower arsenic accumulation in grain," Scientific Reports, vol. 4, no. 8, pp. 5784-5784, 2014.

[49] B. Halliwell and J. M. C. Gutteridge, Free Radicals in Biology and Medicine, Oxford University Press, Oxford, UK, 1999.

[50] T. A. Akhtar, M. A. Lampi, and B. M. Greenberg, "Identification of six differentially expressed genes in response to copper exposure in the aquatic plant Lemna gibba (duckweed)," Environmental Toxicology \& Chemistry, vol. 24, no. 7, pp. 1705-1715, 2005.

[51] L. Xiao, C. Xi, D. J. Oliver, and C. B. Xiang, "Isolation of a low-sulfur tolerance gene from Eichhornia crassipes, using a functional gene-mining approach," Planta, vol. 231, no. 1, pp. 211-219, 2009.

[52] O. Hidalgo, S. Garcia, T. Garnatje et al., "Genome size in aquatic and wetland plants: fitting with the large genome constraint hypothesis with a few relevant exceptions," Plant Systematics and Evolution, vol. 301, no. 7, pp. 1927-1936, 2015.

[53] L. A. Raubeson, R. Peery, T. W. Chumley et al., "Comparative chloroplast genomics: analyses including new sequences from the angiosperms Nuphar advena and Ranunculus macranthus," BMC Genomics, vol. 8, p. 174, 2007.

[54] E. L. Peredo, U. M. King, and D. H. Les, “The plastid genome of Najas flexilis: adaptation to submersed environments is accompanied by the complete loss of the NDH complex in an aquatic angiosperm," PLoS One, vol. 8, no. 7, pp. 88-91, 2013.

[55] T. Huotari and H. Korpelainen, "Complete chloroplast genome sequence of Elodea canadensis and comparative analyses with other monocot plastid genomes," Gene, vol. 508, no. 1, pp. 96-105, 2012.

[56] S. R. Silva, D. G. Pinheiro, E. J. Meer, T. P. Michael, A. M. Varani, and V. F. O. Miranda, "The complete chloroplast genome sequence of the leafy bladderwort, Utricularia foliosa L. (Lentibulariaceae)," Conservation Genetics Resources, vol. 9, no. 2, pp. 213-216, 2016.

[57] A. V. Mardanov, N. V. Ravin, B. B. Kuznetsov et al., "Complete sequence of the duckweed (Lemna minor) chloroplast genome: 
structural organization and phylogenetic relationships to other angiosperms," Journal of Molecular Evolution, vol. 66, no. 6, pp. 555-564, 2008.

[58] W. Wang and J. Messing, "High-throughput sequencing of three Lemnoideae (duckweeds) chloroplast genomes from total DNA," PLoS One, vol. 6, no. 9, 2011.

[59] M. Eisenstein, "The battle for sequencing supremacy," Nature Biotechnology, vol. 30, no. 11, pp. 1023-1026, 2012.

[60] W. Wang, Y. Wu, and J. Messing, "The mitochondrial genome of an aquatic plant, Spirodela polyrhiza," PLoS One, vol. 7, no. 10, pp. 135-139, 2012.

[61] A. Cuenca, G. Petersen, and O. Seberg, "The complete sequence of the mitochondrial genome of Butomus umbellatus - a member of an early branching lineage of monocotyledons," PLoS One, vol. 8, no. 4, pp. 542-542, 2013.

[62] W. Wang, G. Haberer, H. Gundlach et al., "The Spirodela polyrhiza genome reveals insights into its neotenous reduction fast growth and aquatic lifestyle," Nature Communications, vol. 5, 2014.

[63] R. Ming, R. Vanburen, Y. Liu et al., "Genome of the long-living sacred lotus (Nelumbo nucifera, Gaertn.)," Genome Biology, vol. 14, no. 5, pp. 241-251, 2013.

[64] A. V. Hoeck, N. Horemans, P. Monsieurs, H. X. Cao, H. Vandenhove, and R. Blust, "The first draft genome of the aquatic model plant Lemna minor, opens the route for future stress physiology research and biotechnological applications," Biotechnology for Biofuels, vol. 8, no. 1, pp. 1-13, 2015.

[65] J. Barta, J. D. Stone, J. Pech et al., "The transcriptome of Utricularia vulgaris, a rootless plant with minimalist genome, reveals extreme alternative splicing and only moderate sequence similarity with Utricularia gibba," BMC Plant Biology, vol. 15, no. 1, pp. 1-14, 2015.

[66] E. Ibarra-Laclette, V. A. Albert, C. A. Péreztorres et al., "Transcriptomics and molecular evolutionary rate analysis of the bladderwort (Utricularia), a carnivorous plant with a minimal genome," BMC Plant Biology, vol. 11, no. 1, pp. 1-16, 2011.

[67] L. Y. Chen, S. Y. Zhao, Q. F. Wang, and M. L. Moody, "Transcriptome sequencing of three Ranunculus species (Ranunculaceae) reveals candidate genes in adaptation from terrestrial to aquatic habitats," Scientific Reports, vol. 5, 2015.

[68] J. Jeon, S. J. Bong, J. S. Park et al., "De novo transcriptome analysis and glucosinolate profiling in watercress (Nasturtium officinale R. Br.)," BMC Genomics, vol. 18, no. 1, p. 401, 2017.

[69] Q. Jiang, F. Wang, H. W. Tan et al., "De novo transcriptome assembly, gene annotation, marker development, and miRNA potential target genes validation under abiotic stresses in Oenanthe javanica," Molecular Genetics and Genomics, vol. 290, no. 2, pp. 671-683, 2015.

[70] Y. Zheng, G. Jagadeeswaran, K. Gowdu et al., "Genome-wide analysis of microRNAs in sacred lotus, Nelumbo nucifera (Gaertn)," Tropical Plant Biology, vol. 6, no. 2-3, pp. 117130, 2013.

[71] L. Pan, X. Wang, J. Jin, X. Yu, and J. Hu, "Bioinformatic identification and expression analysis of Nelumbo nucifera microRNA and their targets," Applications in Plant Sciences, vol. 3, no. 9, article 1500046, 2015.

[72] M. Thudi, Y. Li, S. A. Jackson, G. D. May, and R. K. Varshney, "Current state-of-art of sequencing technologies for plant genomics research," Briefings in Functional Genomics, vol. 11, no. 1, pp. 3-11, 2012.
[73] Y. G. Kim, J. Cha, and S. Chandrasegaran, "Hybrid restriction enzymes: zinc finger fusions to FokI cleavage domain," Proceedings of the National Academy of Sciences, vol. 93, no. 3, pp. 1156-1160, 1996.

[74] T. Li, S. Huang, W. Z. Jiang et al., "TAL nucleases (TALNs): hybrid proteins composed of TAL effectors and FokI DNAcleavage domain," Nucleic Acids Research, vol. 39, no. 1, pp. 359-372, 2011.

[75] M. M. Mahfouz, L. Li, M. Shamimuzzaman, A. Wibowo, $\mathrm{X}$. Fang, and J. K. Zhu, "De novo-engineered transcription activator-like effector (TALE) hybrid nuclease with novel DNA binding specificity creates double-strand breaks," Proceedings of the National Academy of Sciences, vol. 108, no. 6, pp. 2623-2628, 2011.

[76] J. C. Miller, S. Tan, G. Qiao et al., "A TALE nuclease architecture for efficient genome editing," Nature Biotechnology, vol. 29, no. 2, pp. 143-148, 2011.

[77] M. Jinek, K. Chylinski, I. Fonfara, M. Hauer, J. A. Doudna, and E. Charpentier, "A programmable dual-RNA-guided DNA endonuclease in adaptive bacterial immunity," Science, vol. 337, no. 6096, pp. 816-821, 2012.

[78] M. Gurushidze, G. Hensel, S. Hiekel, S. Schedel, V. Valkov, and J. Kumlehn, "True-breeding targeted gene knock-out in barley using designer TALE-nuclease in haploid cells," PLoS One, vol. 9, no. 3, article e92046, 2014.

[79] T. Li, B. Liu, M. H. Spalding, D. P. Weeks, and B. Yang, "High-efficiency TALEN-based gene editing produces disease-resistant rice," Nature Biotechnology, vol. 30, no. 5, pp. 390-392, 2012.

[80] T. Wendt, P. B. Holm, C. G. Starker et al., "TAL effector nucleases induce mutations at a pre-selected location in the genome of primary barley transformants," Plant Molecular Biology, vol. 83, no. 3, pp. 279-285, 2013.

[81] Z. Feng, B. Zhang, W. Ding et al., "Efficient genome editing in plants using a CRISPR/Cas system," Cell Research, vol. 23, no. 10, pp. 1229-1232, 2013.

[82] J. F. Li, J. E. Norville, J. Aach et al., "Multiplex and homologous recombination-mediated genome editing in Arabidopsis and Nicotiana benthamiana using guide RNA and Cas9," Nature Biotechnology, vol. 31, no. 8, pp. 688-691, 2013.

[83] V. Nekrasov, B. Staskawicz, and D. Weigel, "Targeted mutagenesis in the model plant Nicotiana benthamiana using Cas9 RNA-guided endonuclease," Nature Biotechnology, vol. 31, no. 8, pp. 691-693, 2013.

[84] J. Miao, D. Guo, J. Zhang et al., "Targeted mutagenesis in rice using CRISPR-Cas system," Cell Research, vol. 23, no. 10, pp. 1233-1236, 2013.

[85] Q. Shan, Y. Wang, J. Li et al., "Targeted genome modification of crop plants using a CRISPR-Cas system," Nature Biotechnology, vol. 31, no. 8, pp. 686-688, 2013.

[86] S. K. Upadhyay, J. Kumar, A. Alok, and R. Tuli, "RNA-guided genome editing for target gene mutations in wheat," G3-Genes Genomes Genetics, vol. 3, no. 12, pp. 2233-2238, 2013. 

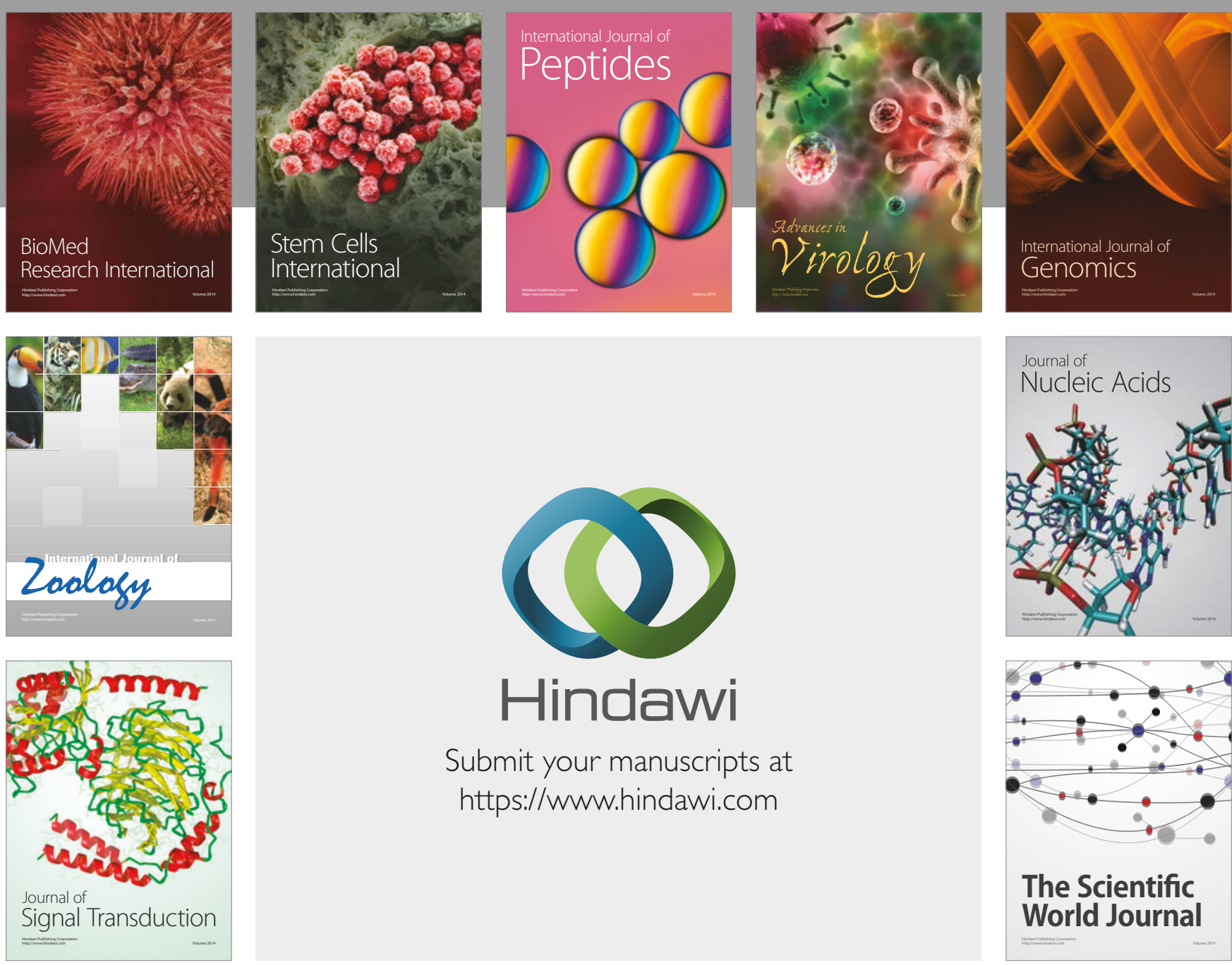

Submit your manuscripts at

https://www.hindawi.com
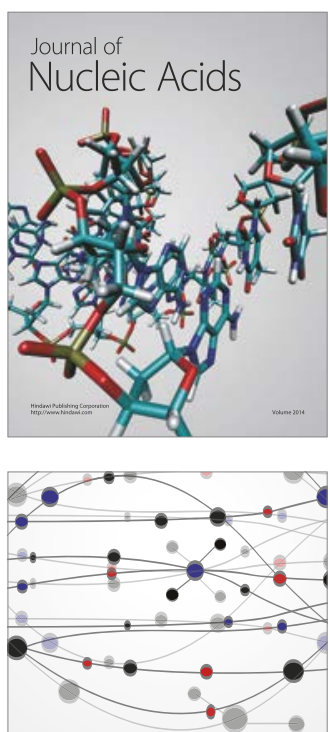

The Scientific World Journal

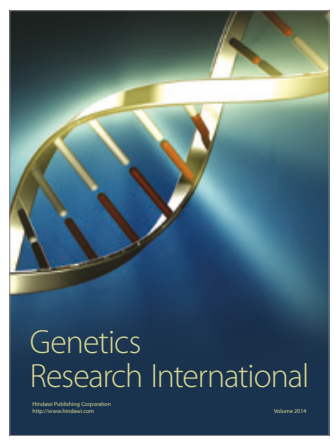

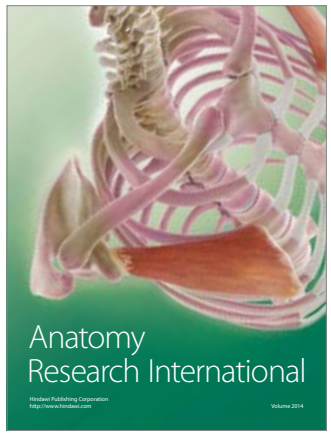

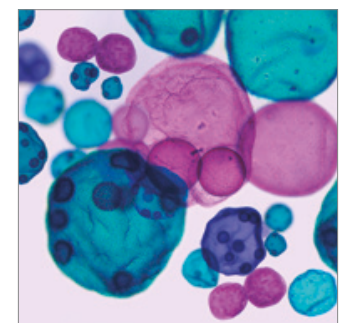

International Journal of Microbiology
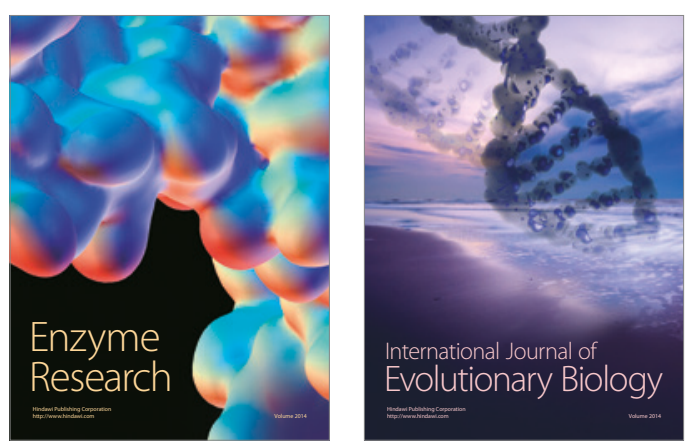
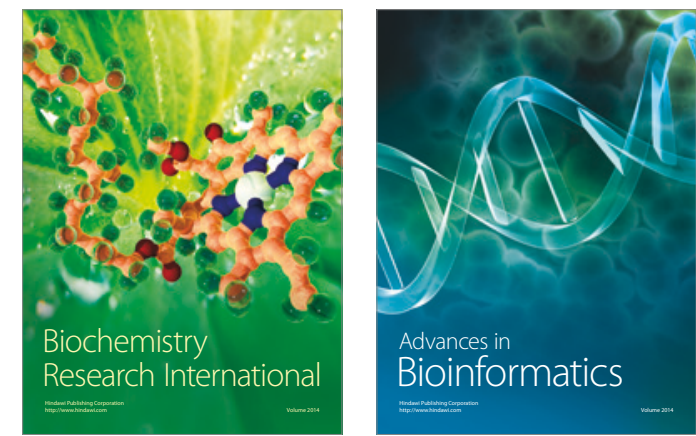

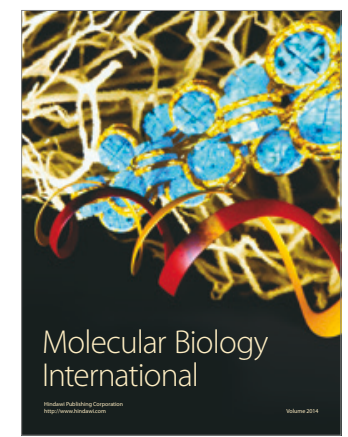

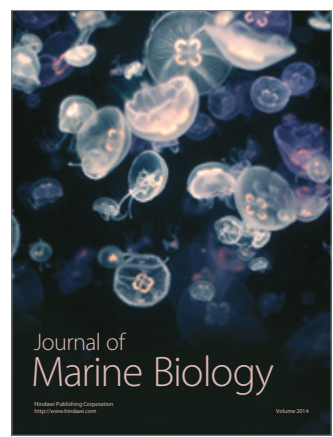

